\title{
Comparison of the Effects of Nonprotein and Protein Nitrogen on Apoptosis and Autophagy of Rumen Epithelial Cells in Goats
}

\author{
Zhiwei Kong ${ }^{1,2,3}$, Chuanshe Zhou ${ }^{1,4, *}$, Jinhe Kang ${ }^{1,4} \mathbb{D}^{-}$and Zhiliang Tan ${ }^{1,4}$ \\ 1 CAS Key Laboratory for Agro-Ecological Processes in Subtropical Region, National Engineering Laboratory \\ for Pollution Control and Waste Utilization in Livestock and Poultry Production, Hunan Provincial Key \\ Laboratory of Animal Nutritional Physiology and Metabolic Process, Institute of Subtropical Agriculture, \\ Chinese Academy of Sciences, Changsha 410125, China; kongzhiwei2013@126.com (Z.K.); \\ kangjh@isa.ac.cn (J.K.); zltan@isa.ac.cn (Z.T.) \\ 2 Key Laboratory of Optoelectronic Devices and Systems of Ministry of Education and Guangdong Province, \\ College of Optoelectronic Engineering, Shenzhen University, Shenzhen 518060, China \\ 3 College of Food Engineering and Biotechnology, Han Shan Normal University, Chaozhou 521041, China \\ 4 Hunan Co-Innovation Center of Safety Animal Production, CICSAP, National Engineering Laboratory for \\ Pollution Control and Waste Utilization in Livestock and Poultry Production, Changsha 410128, China \\ * Correspondence: zcs@isa.ac.cn; Tel.: +86-731-461-5236; Fax: +86-731-461-2685
}

Received: 20 October 2020; Accepted: 5 November 2020; Published: 9 November 2020

Simple Summary: Proteins provide important raw materials for the self-renewal of cells in the gastrointestinal tract. Cell self-renewal is inseparable from the coordination between apoptosis and autophagy. Previous researchers have explored whether different nitrogen sources are linked to activation or inhibition of apoptosis/autophagy. However, information on the regulatory mechanism of apoptosis and autophagy induced by different nitrogen sources among cells in the gastrointestinal tract is limited. This study attempted to compare the effects of different nitrogen sources on apoptosis and autophagy of rumen epithelial cells in goats through molecular biology techniques such as flow cytometry, transmission electron microscopy, and fluorescence microscopy. On the basis of the obtained results, we found that autophagy had a less obvious ameliorative effect on ruminal epithelial cell apoptosis after treatment with protein nitrogen than after treatment with nonprotein nitrogen.

\begin{abstract}
Protein nutrition is particularly important for the self-renewal processes of gastrointestinal epithelial cells. The self-renewal of cells is inseparable from the interaction between apoptosis and autophagy. However, there are few reports on the relationship between different nitrogen sources and apoptosis/autophagy. In this study, the relative protein expression of Bcl-2-associated $\mathrm{X}$ protein(Bax), caspase-3, and p62 was significantly higher $(p<0.05)$, while that of Bcl-xl, Bcl-2, Beclin1, and Microtuble-associated protein light chain 3 (LC3-II) was significantly lower $(p<0.05)$, in the $\mathrm{NH}_{4} \mathrm{Cl}$ group in comparison with the $\mathrm{NH}_{4} \mathrm{Cl}+4$-phenylbutyric acid (4PBA) group. In addition, the relative protein expression of Bax and caspase- 3 was significantly higher $(p<0.05)$, while that of Bcl-2 and Bcl-xl was decreased significantly $(p<0.05)$, in the $\mathrm{NH}_{4} \mathrm{Cl}+3$-Methyladenine (3-MA) group and the methionine (Met) + 3-MA group in comparison with the $\mathrm{NH}_{4} \mathrm{Cl}$ group. Furthermore, the relative protein expression of Beclin1 and LC3B-II was significantly lower $(p<0.05)$, while that of p62 was significantly higher $(p<0.05)$, in the $\mathrm{NH}_{4} \mathrm{Cl}+\mathrm{Z}$-VAD-FMK group and the Met $+\mathrm{Z}$-VAD-FMK group in comparison with the $\mathrm{NH}_{4} \mathrm{Cl}$ group. In conclusion, our results suggested that endoplasmic reticulum (ER) stress played a critical role in the crosstalk between apoptosis and autophagy induced by $\mathrm{NH}_{4} \mathrm{Cl}$ and Met. Autophagy had a more obvious ameliorative effect on ruminal epithelial cell apoptosis after treatment with nonprotein nitrogen than after treatment with protein nitrogen. These findings may reveal the molecular mechanism of apoptosis and autophagy induced by nonprotein nitrogen and protein nitrogen.
\end{abstract}


Keywords: ammonium chloride; methionine; apoptosis; autophagy

\section{Introduction}

Apoptosis, which plays a pivotal role in tissue homeostasis by eliminating damaged or unnecessary cells in response to various stimuli, is the main cause of the shedding of normal intestinal mucosal epithelial cells and is closely related to the regeneration and repair of gastrointestinal cells [1]. In addition, exfoliation of mucosal epithelial cells during the renewal of gastrointestinal tissue is the largest contributor to the metabolism of fecal nitrogen in ruminants [2]. Autophagy maintains cellular homeostasis to promote cell survival by removing long-lived proteins and damaged organelles under conditions of starvation or other stresses. In many cases, autophagy negatively regulates apoptosis, whereas apoptosis activation blocks autophagy. Apoptosis and autophagy can be induced by modulating the ROS (oxygen free radical)/MAPK (mitogen-activated protein kinase) [3], PI3K(phosphatidylinositol 3-kinase)/Akt(serine-threonine kinase)/mTOR(mammalian target of rapamyoin) [4], and JNK(Jun N-terminal kinase) and mTOR [5] pathways.

Several amino acids (AAs) are associated with apoptosis/autophagy activation or inhibition. Currently, it is recognized that these AAs participate in the mTORC1 and GCN2/eIF2(Protein kinase GCN2/Eukaryotic initiation factor 2) pathways, regulating protein translation and controlling cell AA requirements by simultaneously regulating autophagy-dependent catabolism [6]. For example, methionine (Met) can reduce apoptosis of lymphocytes in peripheral blood and increase the Bcl-2(B-cell lymphoma-2 protein)/Bax(Bcl-associated protein X) ratio [7]. Researchers have found that exogenous Met also inhibits autophagy in liver cells treated via in vitro perfusion [8]. Additionally, studies have shown that Met regulates autophagy in BMECs(bovine mammary epithelial cells) through the PI3K/mTOR signaling pathway [9]. Notably, it has been reported that nonprotein nitrogen (NPN), such as that in ammonium chloride $\left(\mathrm{NH}_{4} \mathrm{Cl}\right)$, induces apoptosis by increasing oxidative damage and Cyt $C($ Cytochrome $C)$ release [10-12]. When ammonia is present in excess, it can cause alkaline chemical burns of the mucosa [13]. Furthermore, $\mathrm{NH}_{4} \mathrm{Cl}$ can inhibit autophagy through the p38 MAPK pathway $[14,15]$.

AAs, the most basic units used for metabolic activity in gastrointestinal tissue, are utilized by epithelial cells for protein synthesis to meet the growth, reproduction and metabolism needs of cells. $\mathrm{NH}_{4} \mathrm{Cl}$ is widely used as a source of NPN in livestock production. However, there have been few reports on the differences between apoptosis and autophagy induced by different nitrogen sources. Therefore, this study compared the effects of different nitrogen sources on apoptosis and autophagy in goat rumen epithelial cells. The findings will help elucidate the mechanisms of self-renewal in gastrointestinal epithelial cells and endogenous nitrogen secretion in ruminants.

\section{Materials and Methods}

\subsection{Culture and Treatment of Primary Ruminal Epithelial Cells (PRECs)}

The rumen tissues of healthy black goats were repeatedly rinsed with normal saline and then placed into phosphate-buffered saline (PBS) containing streptomycin, amphotericin B, and gentamicin for storage until use. Isolation, purification, identification, and culture of the PRECs were conducted on the basis of previously described methods [16]. Briefly, the epithelial layer of rumen tissue was separated from the muscle layer, added to a digestive solution containing $2.5 \%$ trypsin, and incubated for $5 \mathrm{~min}$ at $37^{\circ} \mathrm{C}$. The epithelial tissues were digested 5 times; the supernatant was discarded after the first 2 digestions, while the supernatant and precipitates were saved after the final 3 digestions. Then, the cells were resuspended in complete medium, inoculated into culture dishes, and cultured in an incubator at $37^{\circ} \mathrm{C}$. The medium was changed every 2 days. The purified cells were cultured in Dulbecco's modified Eagle's medium: Nutrient Mixture F-12 (DMEM/F12; Invitrogen, Carlsbad, CA, 
USA) containing 5\% fetal bovine serum (FBS; Gibco, Grand Island, NE, USA), penicillin (100 units $/ \mathrm{mL}$, Invitrogen, Carlsbad, CA, USA)-streptomycin $(0.1 \mathrm{mg} / \mathrm{mL}$, Invitrogen, Carlsbad, CA, USA), gentamicin (25 g/mL, Invitrogen, Carlsbad, CA, USA), and amphotericin B $(2.5 \mathrm{~g} / \mathrm{mL}$, Invitrogen, Carlsbad, CA, USA) at $37{ }^{\circ} \mathrm{C}$ in a cell incubator containing $5 \% \mathrm{CO}_{2}$ at a constant temperature and humidity. Met-free medium was prepared on the basis of the DMEM/F12 formula. $\mathrm{NH}_{4} \mathrm{Cl}$ was freshly diluted in Met-free medium and added to the culture medium before treatment on the basis of the DMEM/F12 formula. When the PRECs reached 70\% confluency, the cells were starved for $6 \mathrm{~h}$ in Met-free medium, and then cultured with the fresh medium containing $5 \mathrm{mM}$ Met (control group) or $5 \mathrm{mM} \mathrm{NH}_{4} \mathrm{Cl}$ (treatment group) for $36 \mathrm{~h}$ (proliferation stage).

\subsection{Morphological Detection}

The fluorochrome Hoechst 33,342 (14,533, Sigma, MO, USA) was applied to detect chromatin condensation as previously described [17], and 4-phenylbutyric acid (4PBA) was added to confirm the role of endoplasmic reticulum (ER) stress in apoptosis. Briefly, after treatment for $36 \mathrm{~h}$ with $5 \mathrm{mM}$ Met or $\mathrm{NH}_{4} \mathrm{Cl}$, PRECs were fixed for $30 \mathrm{~min}$ at $4{ }^{\circ} \mathrm{C}$ with $4 \%$ paraformaldehyde. Then, the cells were treated with PBS (5 min per wash). The cells were then incubated with Hoechst $33,342(8 \mu \mathrm{g} / \mathrm{mL})$ in the dark for $30 \mathrm{~min}$ at room temperature. Finally, the cells were observed under a fluorescence microscope to determine the ratio of apoptotic nuclei.

\subsection{Monodansylcadaverine (MDC) Staining Analysis}

MDC (KGATG002, KeyGEN, Nanjing, China) was used as a tracer for autophagy [18]. After PRECs were treated for $36 \mathrm{~h}, \mathrm{MDC}(50 \mu \mathrm{m})$ was added, and the cells were incubated in the dark for $20 \mathrm{~min}$ at a constant temperature of $37^{\circ} \mathrm{C}$ in a $5 \% \mathrm{CO}_{2}$ incubator. The morphological changes related to autophagy were observed by fluorescence microscopy.

\subsection{Apoptosis Detection by Flow Cytometry}

PRECs were inoculated into 6-well plates at a density of $1 \times 10^{6}$ cells per well and cultured with Met or $\mathrm{NH}_{4} \mathrm{Cl}$. The cells were collected, centrifuged at $1500 \mathrm{rpm}$ for $5 \mathrm{~min}$, and then resuspended in $500 \mu \mathrm{L}$ of binding buffer. Finally, the cells were incubated with $5 \mu \mathrm{L}$ of annexin V-FITC(Fluorescein Isothiocyanate, Nanjing, Jiangsu, China) and $5 \mu \mathrm{L}$ of propidium iodide (PI) (Annexin V-FITC/PI Apoptosis Detection Kit, KGA108, KeyGEN) in the dark for $15 \mathrm{~min}$ at room temperature. Flow cytometry (BD FACScalibur, San Jose, CA, USA) was used to analyze the apoptosis rate.

\subsection{Intracellular ROS Detection}

Cells were collected and exposed to pre-warmed PBS containing DCFHDA(2,7-Dichlorodi -hydrofluorescein diacetate) $(10 \mu \mathrm{M})$ for $1 \mathrm{~h}$ at $37^{\circ} \mathrm{C}$. Then, the cells were washed and resuspended in PBS. Finally, a flow cytometer was used to detect the fluorescence intensities of cells at an excitation/ emission wavelength of 488/525 nm. FlowJo software (FlowJo, Version 7.6.1; TreeStar, Ashland, OR, USA) was applied to analyze the fluorescence intensities data.

\subsection{Detection of Mitochondrial Membrane Potential (MMP)}

A JC-1 assay kit (MCE3520-43-2, Shanghai, China) was used to measure the MMP [17]. Cells were collected, washed with PBS, and then incubated with JC-1 $(10 \mu \mathrm{g} / \mathrm{mL})$ in the dark for $20 \mathrm{~min}$ at $37^{\circ} \mathrm{C}$. Finally, a flow cytometer was used to detect the fluorescence intensity of the cells (BD FACScalibur).

\subsection{Transmission Electron Microscopy (TEM) Analysis}

After treatment with $5 \mathrm{mM}$ Met or $\mathrm{NH}_{4} \mathrm{Cl}$ for $36 \mathrm{~h}$, PRECs were fixed successively with $1 \%$ osmic acid fixation solution and $2.5 \%$ glutaraldehyde for more than $2 \mathrm{~h}$. Then, the cells were washed with phosphate buffer $(0.1 \mathrm{mM})$ and dehydrated with a gradually increasing concentrations of acetone. 
After this, they were coated with epoxy resin, the cell samples were sliced. A transmission electron microscope (JEM-2000EX, JEOL Co, Tokyo, Japan) was applied to collect the electron images [17].

\subsection{Tandem mCherry-EGFP-LC3 Immunofluorescence}

Cells were transfected with a rAd-mCherry-GFP-LC3B((Green fluorescent protein-microtubule associated protein-2) plasmid using Lipofectamine 2000 (Invitrogen, Carlsbad, CA, USA) according to the manufacturer's instructions. At $24 \mathrm{~h}$ after transfection, the cells were treated with DMEM/F12 with 10\% FBS and penicillin-streptomycin (Corning, 30-001-CI) for another $36 \mathrm{~h}$. The fluorescence of rAd-mCherry-GFP-LC3B was observed. The autophagosomes (green dots) and autolysosomes (red dots) in each cell were counted under fluorescence microscopy (Leica DM2500). The rAd-mCherry-GFP-LC3B plasmid was purchased from Honor Gene (HG-rAd022867, Changsha, Hunan, China).

\section{9. $R T-P C R$}

After treatment for $36 \mathrm{~h}$ with $5 \mathrm{mM}$ Met or $\mathrm{NH}_{4} \mathrm{Cl}$, total RNA was extracted using AccuZol Total RNA Extraction Reagent (Bioneer, Daejeon, Korea) on the basis of the manufacturer's instructions [19]. Then, DNaseI (Thermo Scientific, Waltham, MA, USA) was used to eliminate genomic DNA, and a Nano Drop 2000 (Thermo Scientific, Waltham, MA, USA) was used to evaluate the RNA quality and quantity. Then, a Prime Script RT Reagent Kit (Takara, Dalian, China) was applied to reverse-transcribe the RNA into cDNA(complementary Deoxyribonucleic acid). The $2^{-\Delta \Delta C T}$ method was used to determine the relative mRNA expression levels [20]. The details of the primers used for the various genes are shown in Table 1.

Table 1. Gene primers.

\begin{tabular}{|c|c|c|c|}
\hline Gene Name & GeneBank No. & Primer Sequence $\left(5^{\prime}-3^{\prime}\right)$ & Product Size $(\mathrm{bp})$ \\
\hline \multirow{3}{*}{ Beclin1 } & \multirow{3}{*}{ XM_017025264 } & CTGAGGGATGGAAGGGTC & \multirow{3}{*}{159} \\
\hline & & & \\
\hline & & TGGGCTGTGGTAAGTAATG & \\
\hline \multirow{3}{*}{ LC3B } & \multirow{3}{*}{ XM_011529083 } & CGGGTTGAGGAGACACACAA & \multirow{3}{*}{141} \\
\hline & & & \\
\hline & & ATGAG CCGGACATCTTCCAC & \\
\hline \multirow{3}{*}{ p62 } & \multirow{3}{*}{ XM_018051607 } & CCATGCAGGTGAGCTTCGT & \multirow{3}{*}{155} \\
\hline & & & \\
\hline & & GAATCTGCGAGAGACACCATC & \\
\hline \multirow{3}{*}{ Bcl-2 } & \multirow{3}{*}{ XM_005696234 } & GCTACGACACGGAGTTCCA & \multirow{4}{*}{113} \\
\hline & & & \\
\hline & & CCCAGTTGATGCCGCTCT & \\
\hline \multirow{4}{*}{ BCL-XL } & & GAGCTGGTTGACTTTCTC & \\
\hline & \multirow{3}{*}{ XM_006498612 } & & \\
\hline & & TCCATCTCCGATTCAGTCCCT & 142 \\
\hline & & TGAAGCGCATTGGAGATG & \multirow{4}{*}{185} \\
\hline \multirow[t]{3}{*}{ Bax } & \multirow[t]{3}{*}{ XM_013971446.2 } & & \\
\hline & & GGCCTTGAGCACCAGTTT & \\
\hline & & GAATGTCCGAATGAAGCG & \\
\hline \multirow[t]{2}{*}{ p53 } & \multirow[t]{2}{*}{ XM_005693530 } & & \multirow[t]{2}{*}{121} \\
\hline & & $\begin{array}{l}\text { CGTAGTTGCCAGGGTAGG } \\
\text { ATGGCTACTGCTGCGTCGT }\end{array}$ & \\
\hline \multirow[t]{2}{*}{$\beta$-actin } & \multirow[t]{2}{*}{ AF481159.1 } & & \multirow[t]{2}{*}{161} \\
\hline & & TTGAAGGTGGTCTCGTGGAT & \\
\hline
\end{tabular}

\subsection{Western Blot Analysis}

Protein isolation and Western blot analysis were conducted on the basis of previously described methods [21,22]. Briefly, each sample and a pre-stained standard were electrophoretically separated on 
10\% SDS-polyacrylamide gels (Bio-Rad Laboratories, Berkeley, CA, USA). The separated proteins were transferred to polyvinylidene fluoride (PVDF) membranes (Bio-Rad Laboratory) at a constant current $200 \mathrm{~mA}$ for $70 \mathrm{~min}$. The PVDF membranes were incubated overnight in a solution containing primary antibodies (see Table 2) at $4{ }^{\circ} \mathrm{C}$, washed 5 times, and then incubated with secondary antibodies (1:6000, Proteintech) at room temperature for $2 \mathrm{~h}$ while protected from light. An Alpha Imager 2200 digital imaging system (Digital Imaging System, Kirchheim, Germany) was used to obtain and analyze images.

Table 2. Details of the primary antibodies.

\begin{tabular}{ccccc}
\hline Name & No. & Host Species & Dilution & Supplier \\
\hline Caspase-3 & 9665s & Rabbit & $1: 1000$ & CST \\
BCL-2 & ab59348 & Rabbit & $1: 1000$ & Abcam \\
BAX & 50599-2-AP & Rabbit & $1: 2000$ & Proteintech \\
P53 & $10442-1-A P$ & Rabbit & $1: 1200$ & Proteintech \\
BCL-XL & $10783-1-A P$ & Rabbit & $1: 1200$ & Proteintech \\
LC3 & ab192890 & Rabbit & $1: 2000$ & Abcam \\
Beclin1 & ab62557 & Rabbit & $1: 1500$ & Abcam \\
p62 & ab155686 & Rabbit & $1: 2000$ & Abcam \\
DAPK1 & $25136-1-A P$ & Rabbit & $1: 1000$ & Proteintech \\
GPR78 & ab198787 & Rabbit & $1: 1000$ & Abcam \\
ATF4 & ab184909 & Rabbit & $1: 1000$ & Abcam \\
CHOP & ab179823 & Rabbit & $1: 2000$ & Abcam \\
B-actin & ab179467 & Rabbit & $1: 5000$ & Abcam \\
\hline
\end{tabular}

\subsection{Statistical Analysis}

SPSS Statistical Software was used to analyze the data obtained. ROS levels, apoptosis rates, fluorescence intensity, autophagosome numbers, relative apoptotic and autophagic gene mRNA expression, LC3 spot numbers, protein abundance, and ER cavity size were analyzed using one-way ANOVA followed by Tukey-Kramer multiple comparisons tests. The data are shown as the mean \pm SD.

\section{Results}

\subsection{Apoptosis and Autophagy Induction by $\mathrm{NH}_{4} \mathrm{Cl}$ and Met in PRECs}

The PRECs in the Met group showed normal shapes with round, intact nuclei, whereas the cells treated with $\mathrm{NH}_{4} \mathrm{Cl}$ showed nuclear shrinkage, chromatin condensation, or fragmentation (Figure 1A). In addition, the apoptosis rate was significantly higher $(p<0.05)$ in the $\mathrm{NH}_{4} \mathrm{Cl}$ supplementation group than in the Met group (Figure 1B). The MMP change in the $\mathrm{NH}_{4} \mathrm{Cl}$ group was significantly larger $(p<0.05)$ than that in the Met group (Figure 1C). Cytoplasmic ROS levels were higher $(p<0.05)$ in $\mathrm{NH}_{4} \mathrm{Cl}$-treated cells than in Met-treated cells (Figure 1D). Compared with Met addition, $\mathrm{NH}_{4} \mathrm{Cl}$ addition significantly increased $(p<0.05)$ the expression of Bax and caspase- 3 at the mRNA and protein levels, while significantly decreasing $(p<0.05)$ the expression of Bcl-xl and Bcl-2 (Figure 1E). 

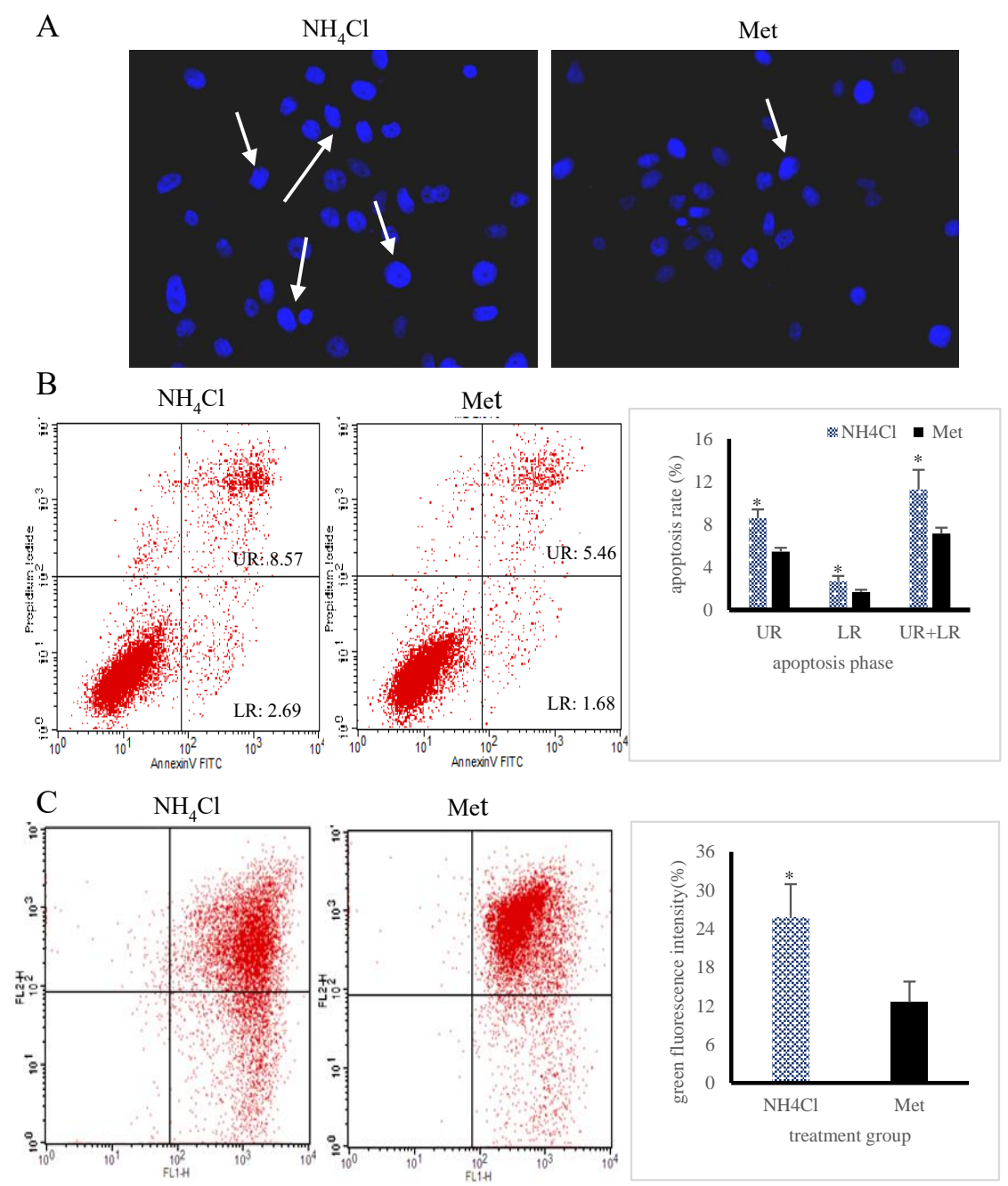

D
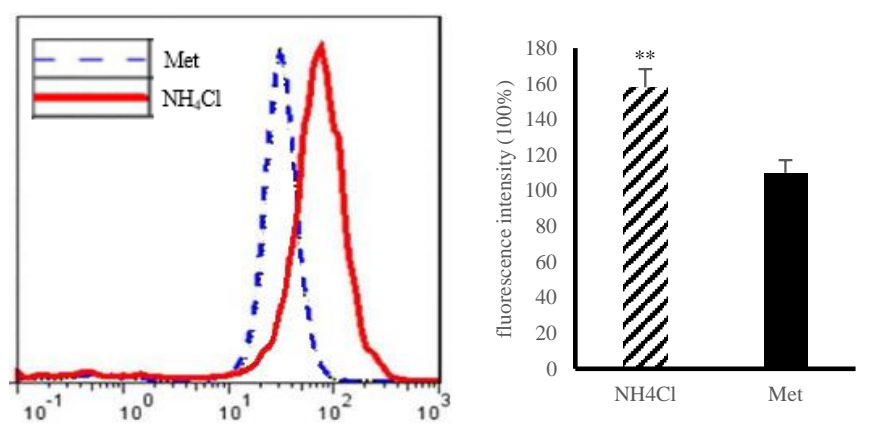

E

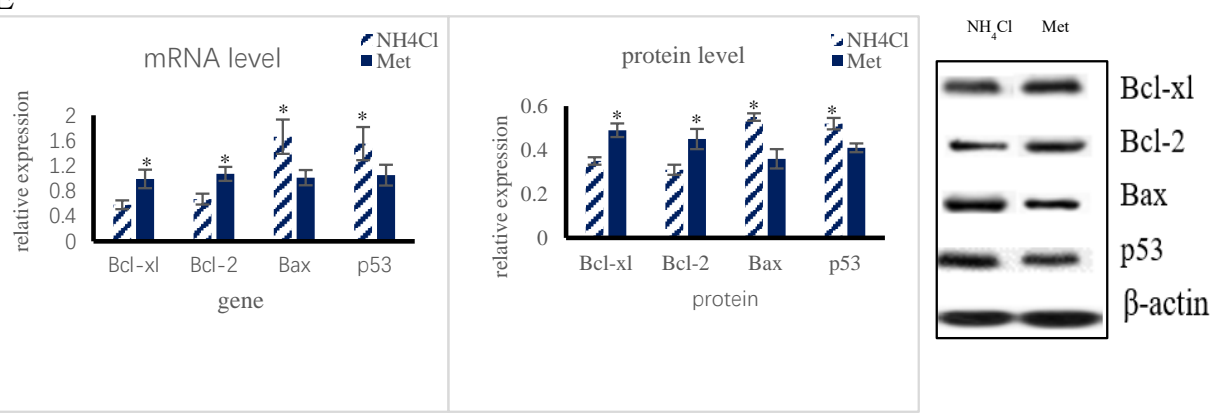

Figure 1. Changes of cell apoptosis after treatment with different nitrogen sources $(n=3)$. (A) Hoechst 33,342 staining in primary ruminal epithelial cells (PRECs) after $36 \mathrm{~h}$ treatment with $5 \mathrm{mM} \mathrm{NH}_{4} \mathrm{Cl}$ and 
methionine (Met). (B) Apoptosis rate percentage under $\mathrm{NH}_{4} \mathrm{Cl}$ and Met detected by flow cytometry. (C) Changes of mitochondrial membrane potential (MMP) under $\mathrm{NH}_{4} \mathrm{Cl}$ and Met detected by flow cytometry. (D) A histogram shows DCF fluorescence in the PRECs. In the histogram, the rise of ROS levels is shown as a shift to the right and a reverse decline to the left. (E) Expression of apoptotic genes and proteins under $\mathrm{NH}_{4} \mathrm{Cl}$ and Met detected by RT-PCR and Western blot. The data are expressed as mean $\pm \mathrm{SD}$. Compared with the control, ${ }^{*} p<0.05$ and ${ }^{* *} p<0.01$ show that the difference is statistically significant.

The cytoplasmic fluorescence intensity was higher $(p<0.05)$ in $\mathrm{NH}_{4} \mathrm{Cl}$-treated cells than in Met-treated cells (Figure 2A). In addition, the number of autophagosomes per cell was higher $(p<0.05)$ in $\mathrm{NH}_{4} \mathrm{Cl}$-treated cells than in Met-treated cells (Figure 2B). After GFP-LC3 plasmid transfection, there were more LC3 spots in the $\mathrm{NH}_{4} \mathrm{Cl}$ group $(p<0.05)$ than in the Met group (Figure $2 \mathrm{C}$ ). The mRNA and protein expression levels of LC3-II and Beclin1 were higher $(p<0.05)$, while those of p62 were lower $(p<0.05)$ in $\mathrm{NH}_{4} \mathrm{Cl}$-treated cells in comparison with Met-treated cells (Figure 2D).

A
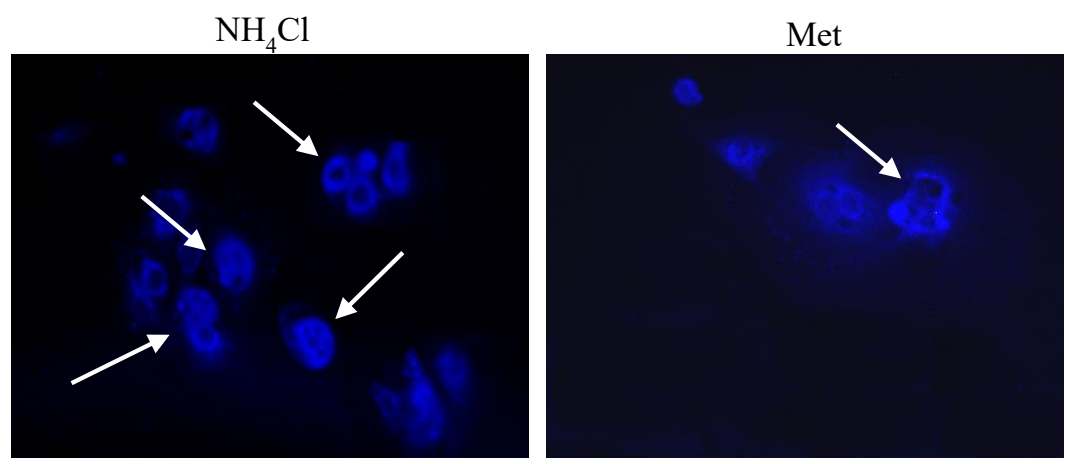

B
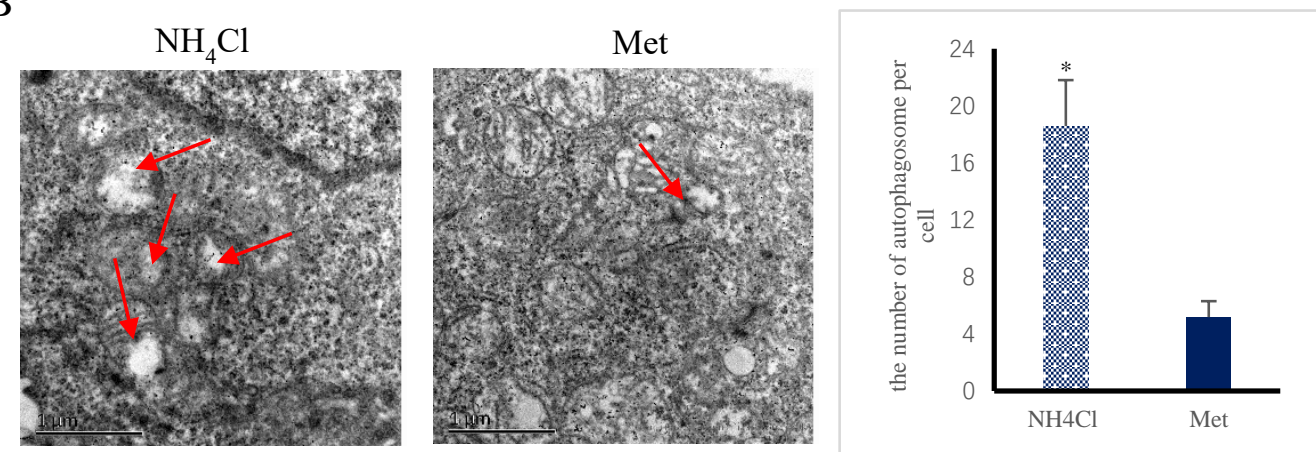

$\mathrm{C}$
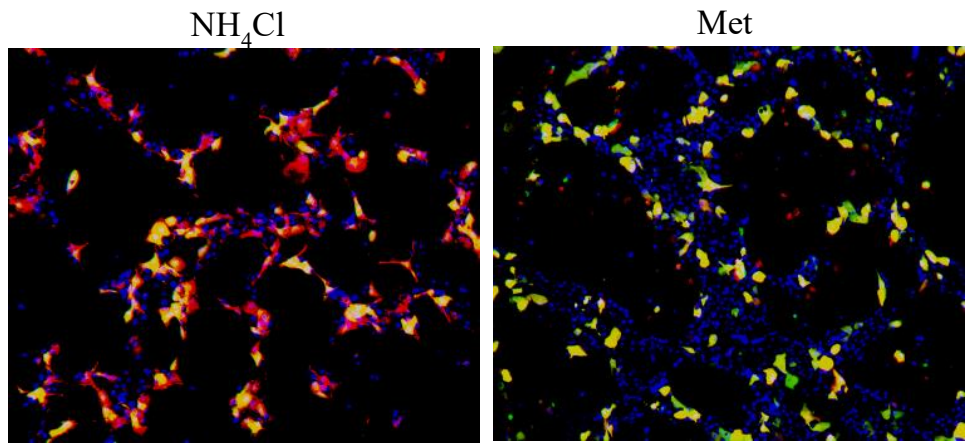

Figure 2. Cont. 
$\mathrm{D}$

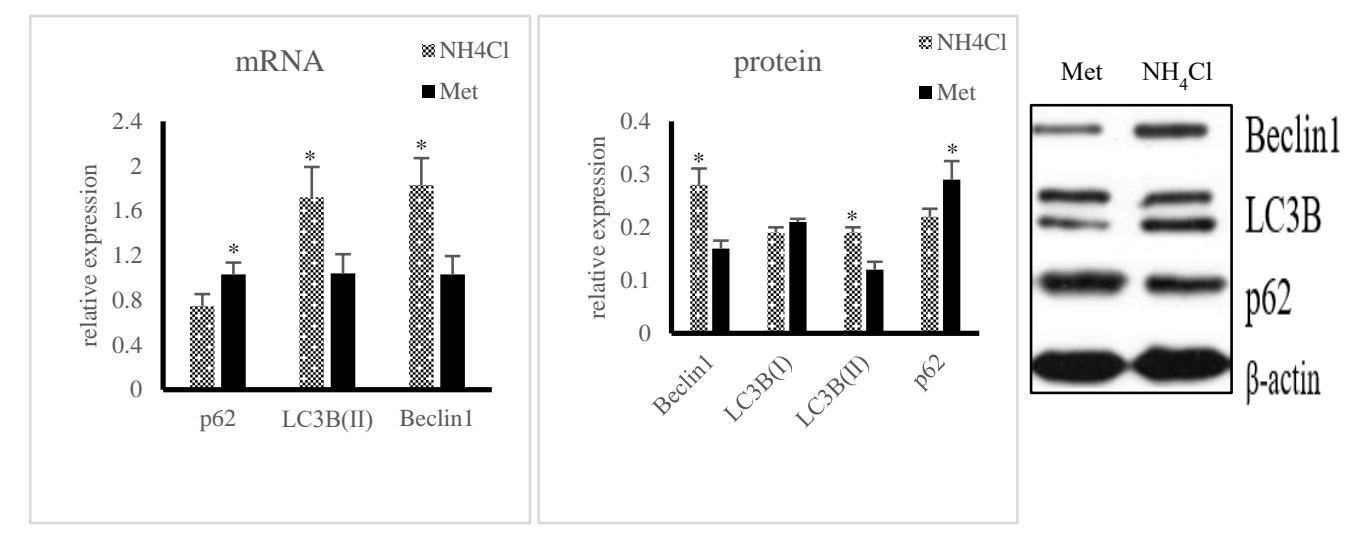

Figure 2. Changes of cell autophagy after treatment with $\mathrm{NH}_{4} \mathrm{Cl}$ and $\mathrm{Met}(n=3)$. (A) Autophagic morphological changes were obtained on the basis of the results of monodansylcadaverine (MDC) staining; images were viewed under a $200 \times$ fluorescence microscope. (B) The cells were fixed and analyzed by transmission electron microscopy $(40,000 \times)$. The number of autophagosomes per cell were determined from at least 15 cells in each group. The data are presented as mean \pm SD. Compared with the control, ${ }^{*} p<0.05$ shows the difference is statistically significant. (C) Immunofluorescence image of endogenous LC3 in PREC culture treated with $\mathrm{NH}_{4} \mathrm{Cl}$ and Met. Green dots represent autophagosomes, red dots represent autolysosomes, blue represents the staining with the Hoechst 33,342, and yellow is a merging of red and green. (D) Expression of autophagic genes and proteins under $\mathrm{NH}_{4} \mathrm{Cl}$ and Met detected by RT-PCR and Western blot.

\subsection{ER Stress Induction by $\mathrm{NH}_{4} \mathrm{Cl}$ and Met in PRECS}

The expansion area of the ER cavity was larger $(p<0.05)$ in $\mathrm{NH}_{4} \mathrm{Cl}$-treated cells than in Met-treated cells (Figure 3A). Concurrently, the protein expression levels of DAPK1(Death-associated Protein Kinase 1), GRP78 (glucose-regulated protein 78), ATF4 (activating transcription factor 4), and CHOP (C/EBP homoiogousprotein) were higher $(p<0.05)$ in the $\mathrm{NH}_{4} \mathrm{Cl}$ group than in the Met group (Figure 3B), while the protein expression levels of DAPK1, GRP78, ATF4, and CHOP were lower $(p<0.05)$ in $\mathrm{NH}_{4} \mathrm{Cl}$ +4 PBA-treated cells than in $\mathrm{NH}_{4} \mathrm{Cl}$-treated cells (Figure 3B). There were no differences $(p>0.05)$ in the protein expression levels of DAPK1, GRP78, ATF4, and CHOP between the Met group $(p>0.05)$ and the $\mathrm{NH}_{4} \mathrm{Cl}+4 \mathrm{PBA}$ group.
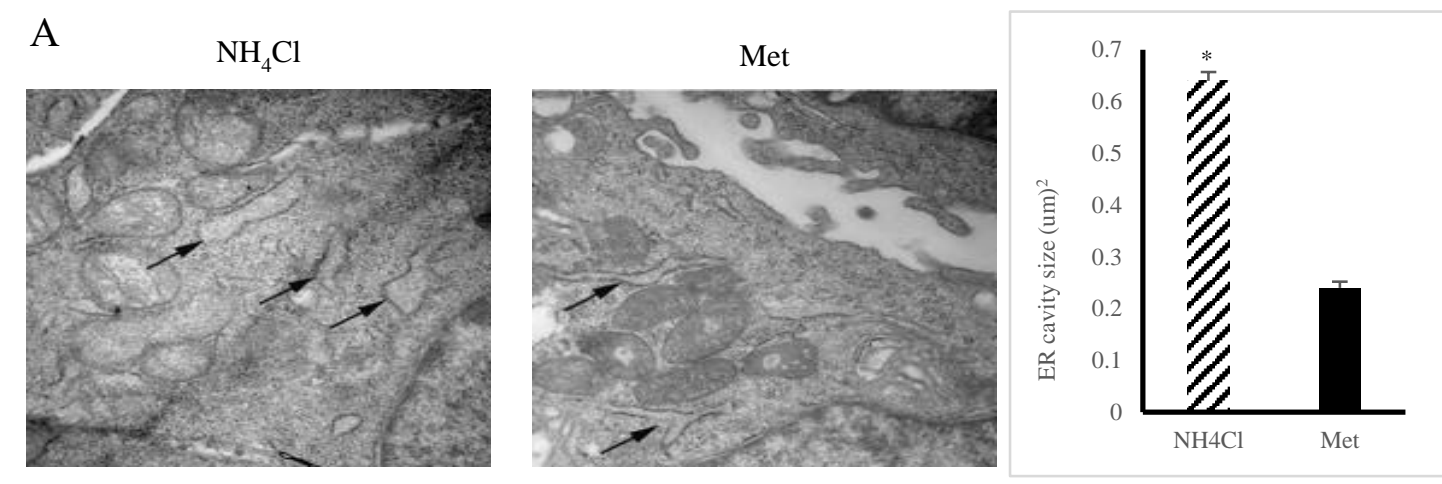

Figure 3. Cont. 
$\mathrm{B}$

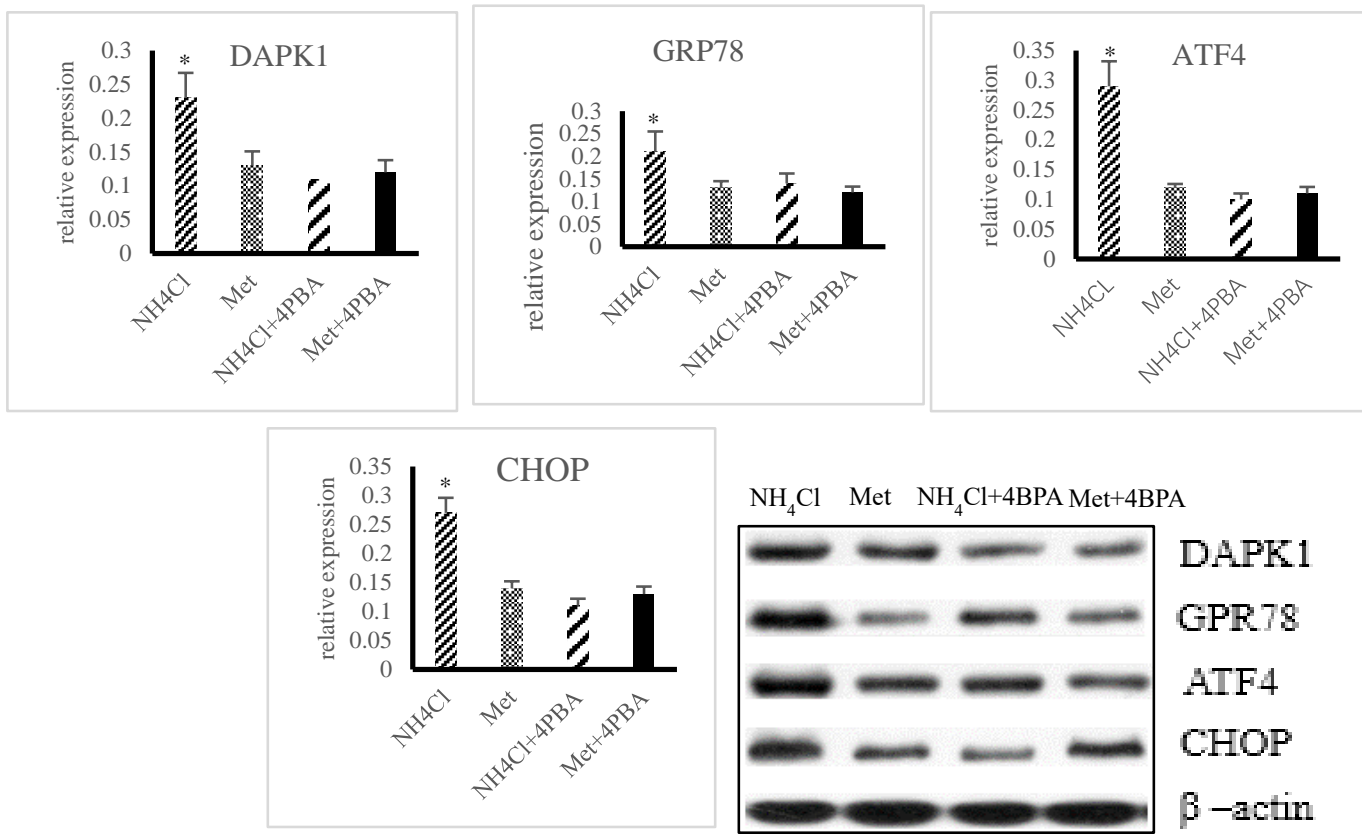

Figure 3. Endoplasmic reticulum (ER) stress induced by nonprotein nitrogen $\left(\mathrm{NH}_{4} \mathrm{Cl}\right)$ and protein nitrogen (Met) sources in PRECs. (A) Morphological changes of ER in nonprotein nitrogen $\left(\mathrm{NH}_{4} \mathrm{Cl}\right.$ ) and protein nitrogen (Met) were obtained by transmission electron microscopy. The images were viewed under a 40,000 $\times$ transmission electron microscope. (B) The expression of ER stress-related proteins was conducted by Western blot. Each bar shows mean \pm SD. " $*$ " means there is a significant difference.

\subsection{Effects of ER Stress on Apoptosis Induced by $\mathrm{NH}_{4} \mathrm{Cl}$ and Met in PRECS}

The cytoplasmic fluorescence intensity was higher $(p<0.05)$ in $\mathrm{NH}_{4} \mathrm{Cl}$-treated cells than in Met-treated cells (Figure 4A), and no significant differences were observed between Met-treated cells and $\mathrm{NH}_{4} \mathrm{Cl}+4 \mathrm{BPA}$ treated cells $(p>0.05)$. There were significantly more $(p<0.05)$ apoptotic cells in the $\mathrm{NH}_{4} \mathrm{Cl}$ group than in the $\mathrm{NH}_{4} \mathrm{Cl}+4 \mathrm{PBA}$ group, while no significant difference $(p>0.05)$ was observed between the Met group and the Met $+4 \mathrm{PBA}$ group $(p>0.05)$. The number of apoptotic cells in the Met $+4 \mathrm{PBA}$ group was not significantly different from that in the $\mathrm{NH}_{4} \mathrm{Cl}+4 \mathrm{PBA}$ group $(p>0.05)$ (Figure 4B). As shown in Figure 4C, compared to cells treated with Met only, cells treated with $\mathrm{NH}_{4} \mathrm{Cl}+4 \mathrm{PBA}$ exhibited significantly higher relative protein expression of Bax and caspase-3 $(p<0.05)$, and Bcl-xl and Bcl-2 protein expression was significantly lower $(p<0.05)$ in the $\mathrm{NH}_{4} \mathrm{C}$ group than in the $\mathrm{NH}_{4} \mathrm{Cl}+4 \mathrm{PBA}$ group. There were no significant differences in the expression of apoptotic proteins in the Met +4 PBA group compared with the Met group $(p>0.05)$ (Figure 4C).

\subsection{Effects of ER Stress on Autophagy Induced by $\mathrm{NH}_{4} \mathrm{Cl}$ and Met in PRECs}

There were significantly fewer $(p<0.05)$ autophagosomes in $\mathrm{NH}_{4} \mathrm{Cl}+4 \mathrm{PBA}$-treated cells than in $\mathrm{NH}_{4} \mathrm{Cl}$-treated cells, while no significant differences $(p>0.05)$ were observed between Met + 4PBA-treated cells and Met-treated cells (Figure 5A,B). After GFP-LC3 plasmid transfection, there were fewer LC3 spots in the $\mathrm{NH}_{4} \mathrm{Cl}+4 \mathrm{PBA}$ group $(p<0.05)$ than in the $\mathrm{NH}_{4} \mathrm{Cl}$ group (Figure $5 \mathrm{C}$ ). The protein expression levels of Beclin1 and LC3-II were lower, while those of p62 were significantly higher $(p<0.05)$, in the $\mathrm{NH}_{4} \mathrm{Cl}+4 \mathrm{PBA}$ group in comparison with the $\mathrm{NH}_{4} \mathrm{Cl}$ group (Figure 5D). The protein expression levels of Beclin1, LC3-II, and p62 in the Met +4 PBA group were not significantly different from those in the Met group $(p>0.05)$. 
A
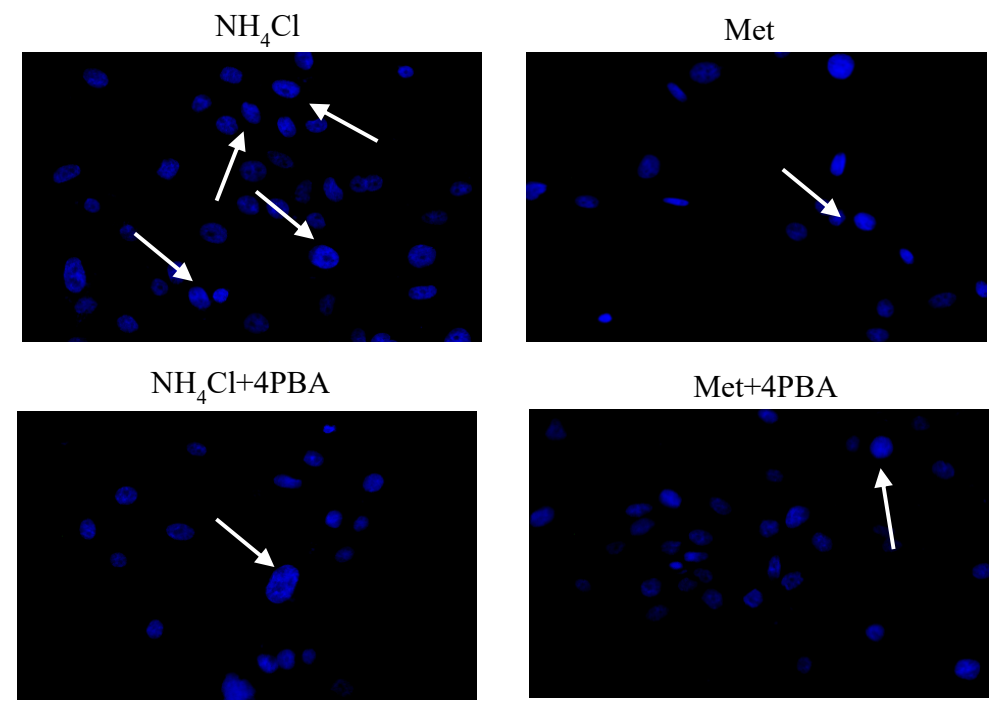

B
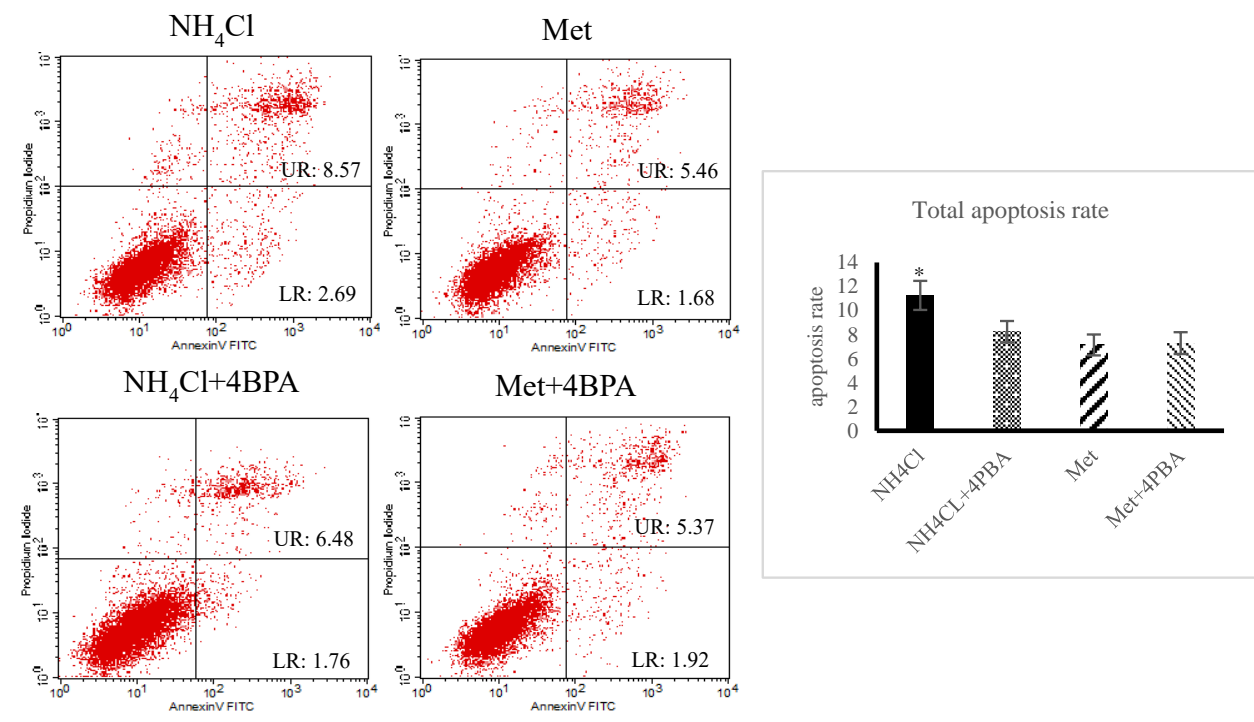

$\mathrm{C}$

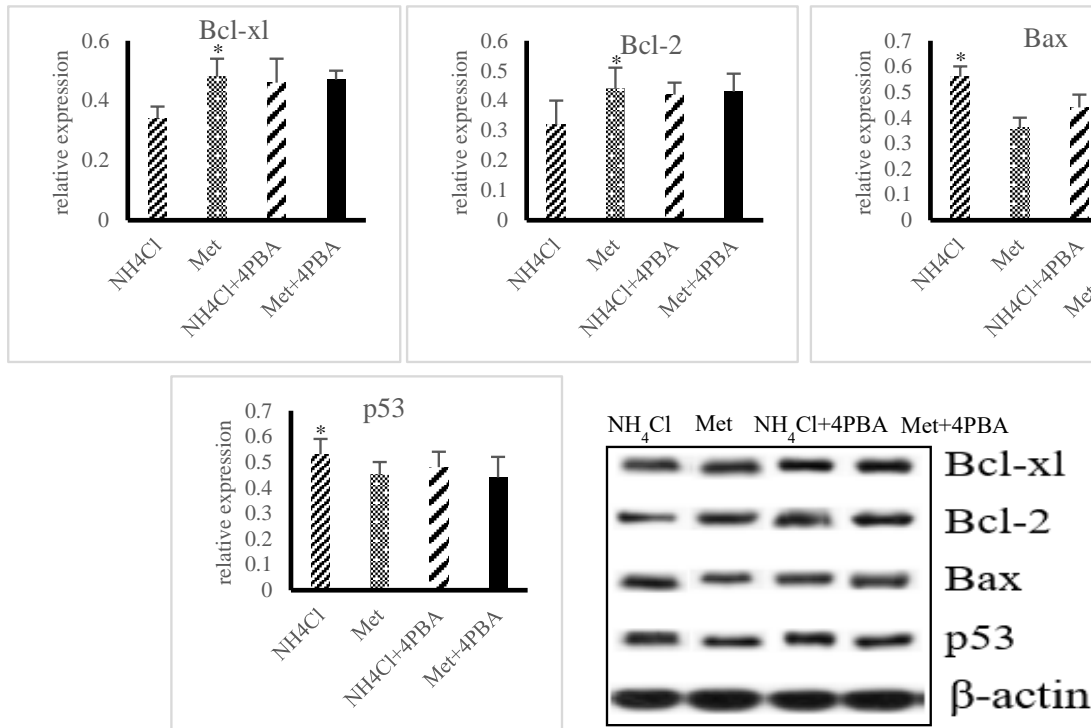

Figure 4. The effects of ER stress on $\mathrm{NH}_{4} \mathrm{Cl}$ and Met-induced apoptosis in PRECs. (A) Apoptotic morphological changes were obtained in PRECs on the basis of Hoechst 33,342 staining. The images 
were viewed under a 200× fluorescence microscope. (B) The effect of 4-phenylbutyric acid (4PBA) on apoptosis rate induced by $\mathrm{NH}_{4} \mathrm{Cl}$ and Met. (C) Western blot was conducted to confirm the role of $4 \mathrm{PBA}$ in apoptosis induced by inorganic nitrogen $\left(\mathrm{NH}_{4} \mathrm{Cl}\right)$ and organic nitrogen (Met). Each bar shows mean \pm SD.

A
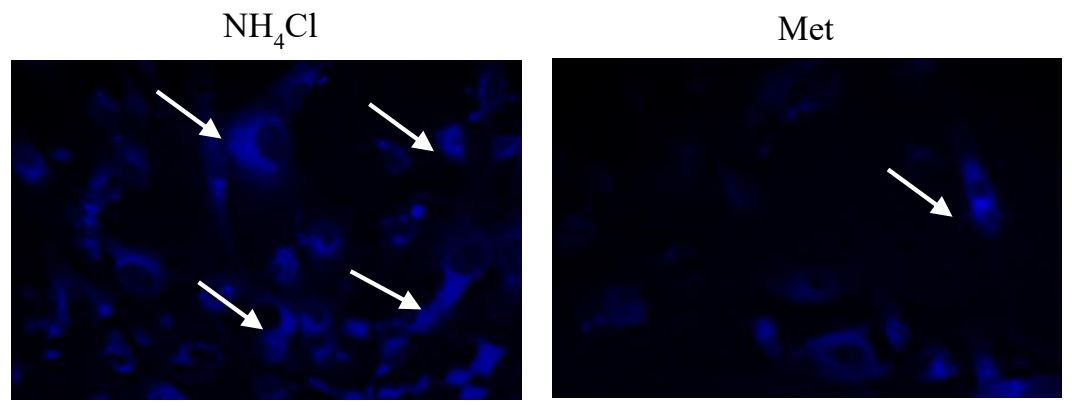

$\mathrm{NH}_{4} \mathrm{Cl}+4 \mathrm{PBA}$

Met+4PBA

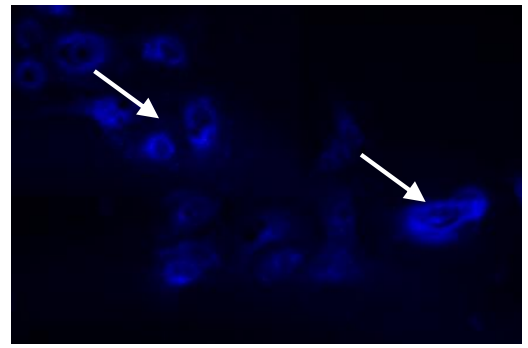

B
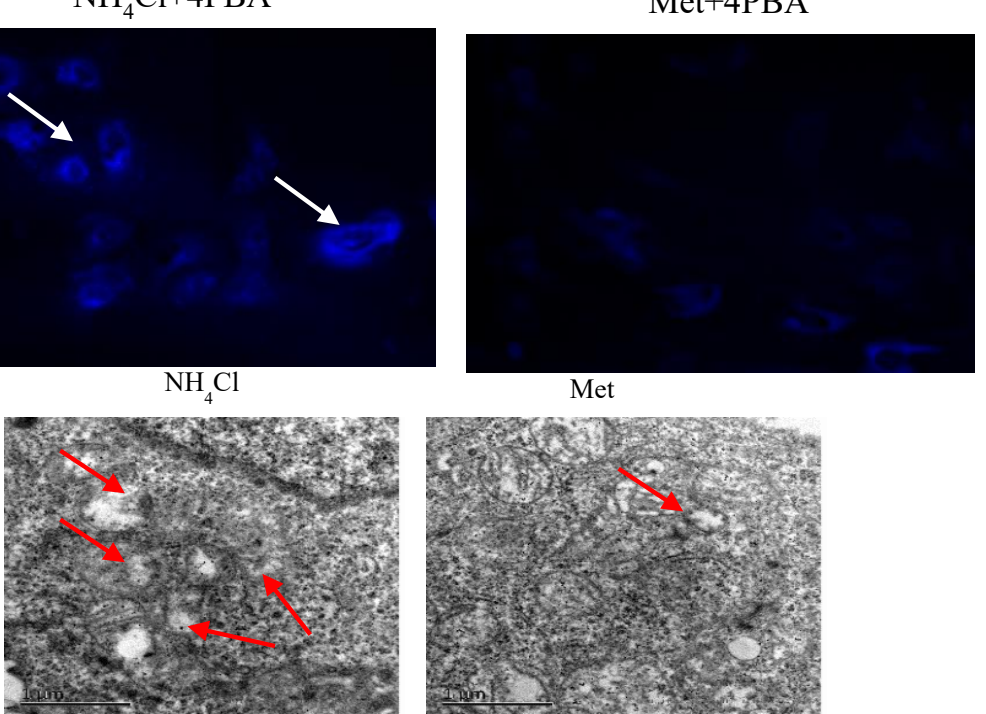

$\mathrm{NH}_{4} \mathrm{Cl}+4 \mathrm{PBA}$

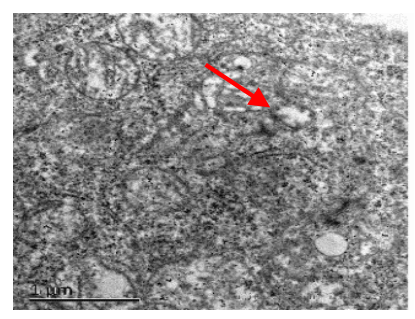

Met+4PBA
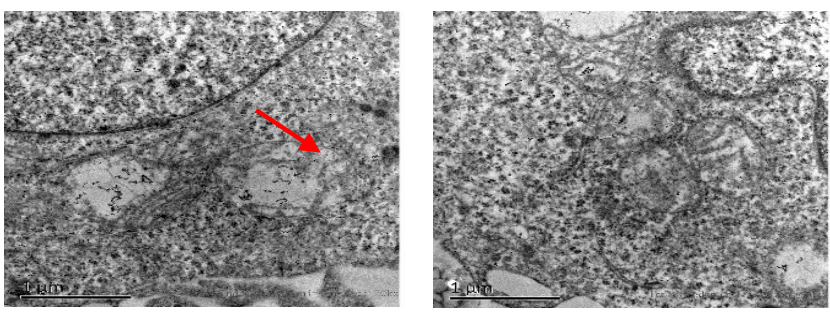

Figure 5. Cont. 
$\mathrm{C}$
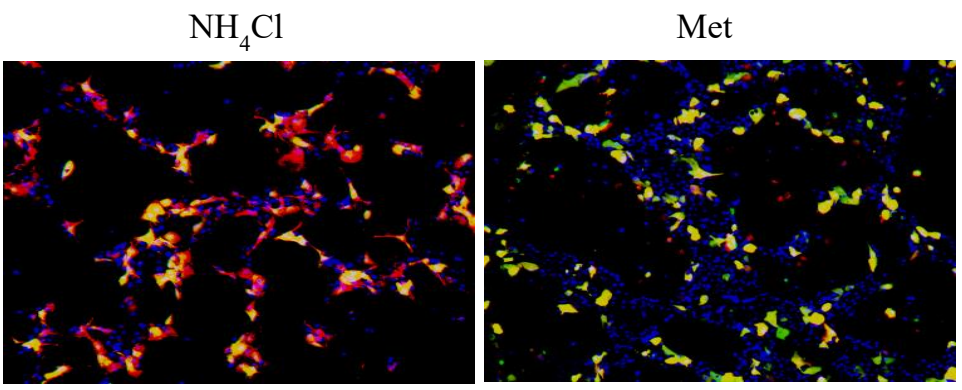

$\mathrm{NH}_{4} \mathrm{Cl}+4 \mathrm{BPA}$

Met+4BPA
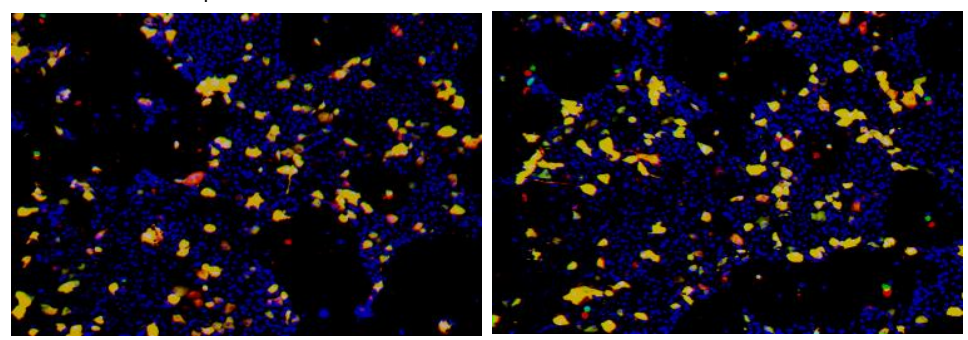

$\mathrm{D}$

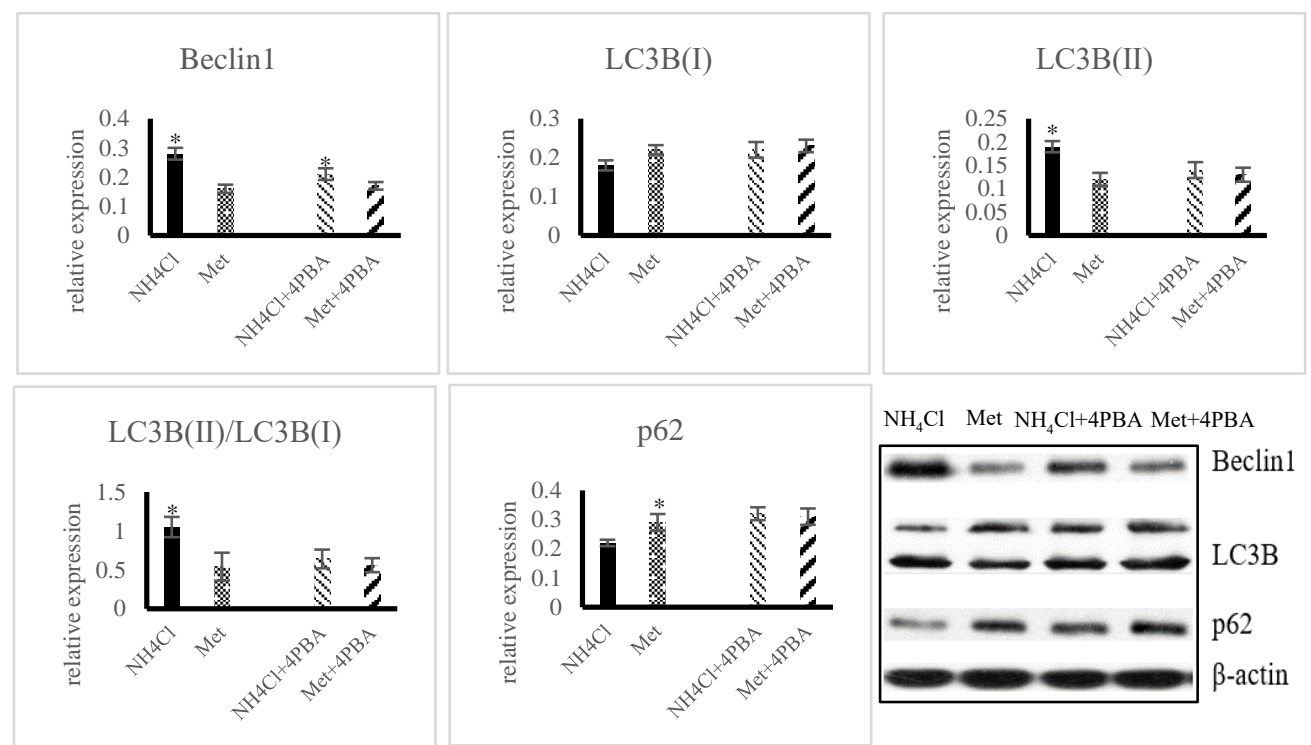

Figure 5. Effects of ER stress in $\mathrm{NH}_{4} \mathrm{Cl}$ and Met-induced autophagy in PRECs. (A) Autophagic morphological changes were observed by fluorescent microscopy using MDC staining; the images were viewed under a 200x fluorescence microscope. (B) The effect of 4PBA on autolysosomes number in PRECs measured by double staining with 3\% uranium acetate and lead nitrate. The images were viewed under a 40,000 $\times$ transmission electron microscope. (C) Immunofluorescence image of endogenous LC3 in PREC cultured treated with $\mathrm{NH}_{4} \mathrm{Cl}$ and Met. Green dots represent autophagosomes, red dots represent autolysosomes. (D) The effect of $4 \mathrm{PBA}$ on relative expression of autophagic proteins was measured by Western blot. Each bar indicates mean $\pm \mathrm{SD}$. Compared with the control, ${ }^{*} p<0.05$ shows the difference is statistically significant.

\subsection{Crosstalk between Apoptosis and Autophagy Induced by $\mathrm{NH}_{4} \mathrm{Cl}$ and Met in PRECs}

The relative protein expression of Bax and caspase-3 was significantly higher $(p<0.05)$, while that of Bcl-2 and Bcl-xl was significantly lower $(p<0.05)$ in the $\mathrm{NH}_{4} \mathrm{Cl}+3-\mathrm{MA}(3-M e t h y l a d e n i n e)$ group than in the $\mathrm{NH}_{4} \mathrm{Cl}$ group. In addition, the relative protein expression of Bax and caspase-3 was significantly lower $(p<0.05)$, while that of Bcl-2 and Bcl-xl was significantly higher $(p<0.05)$, in the Met + 3-MA group in comparison with the $\mathrm{NH}_{4} \mathrm{Cl}$ group (Figure 6A). As shown in Figure 6B, the relative protein expression of Beclin1 and LC3B-II was significantly lower $(p<0.05)$, while that of p62 was significantly 
higher $(p<0.05)$, in the $\mathrm{NH}_{4} \mathrm{Cl}+\mathrm{Z}$-VAD-FMK group in comparison with the $\mathrm{NH}_{4} \mathrm{Cl}$ group, while no significant difference was observed between the Met + Z-VAD-FMK group and the Met group $(p>0.05)$. The protein expression of Beclin1 and LC3-II was significantly higher $(p<0.05)$, while that of p62 was significantly lower $(p<0.05)$, in the $\mathrm{NH}_{4} \mathrm{Cl}$ group in comparison with the Met + Z-VAD-FMK group.

A
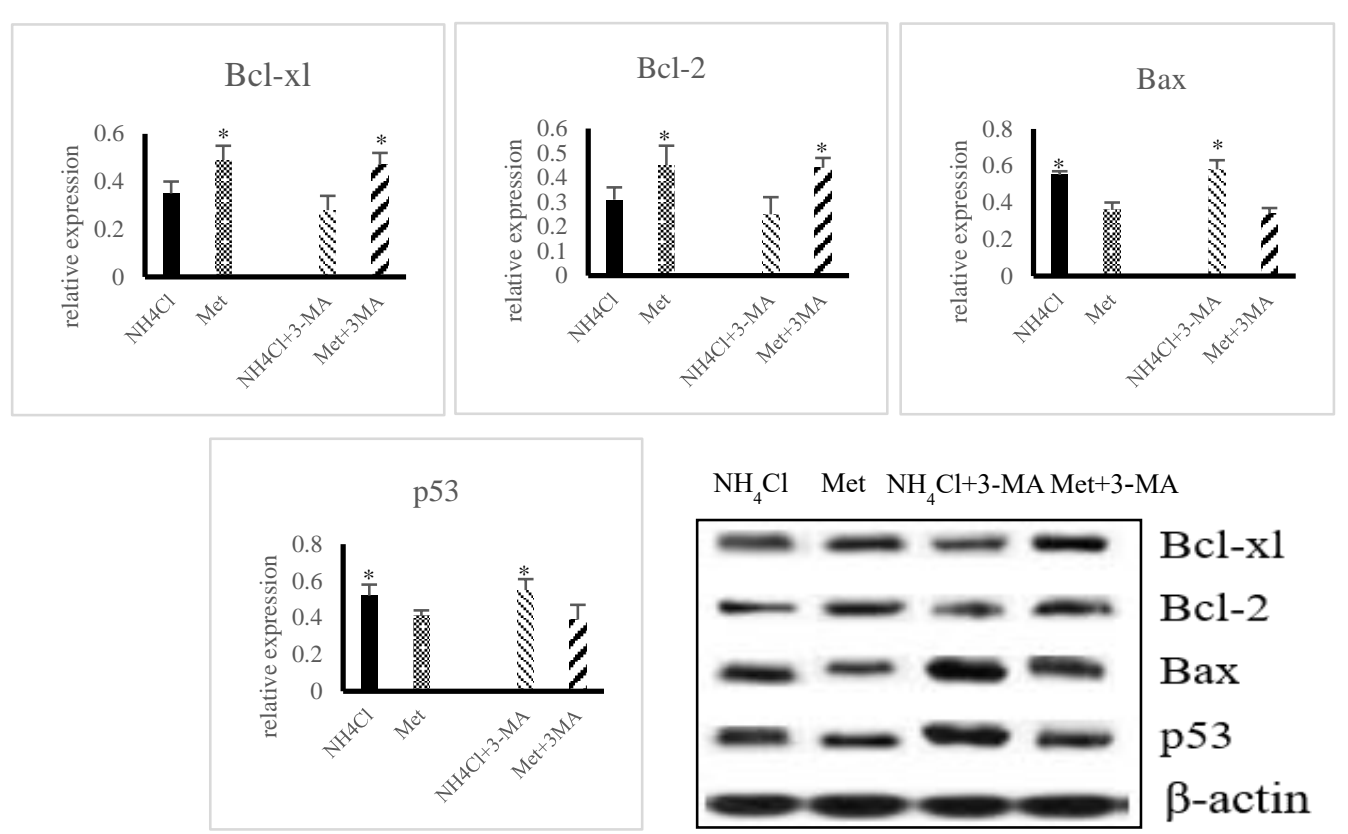

B

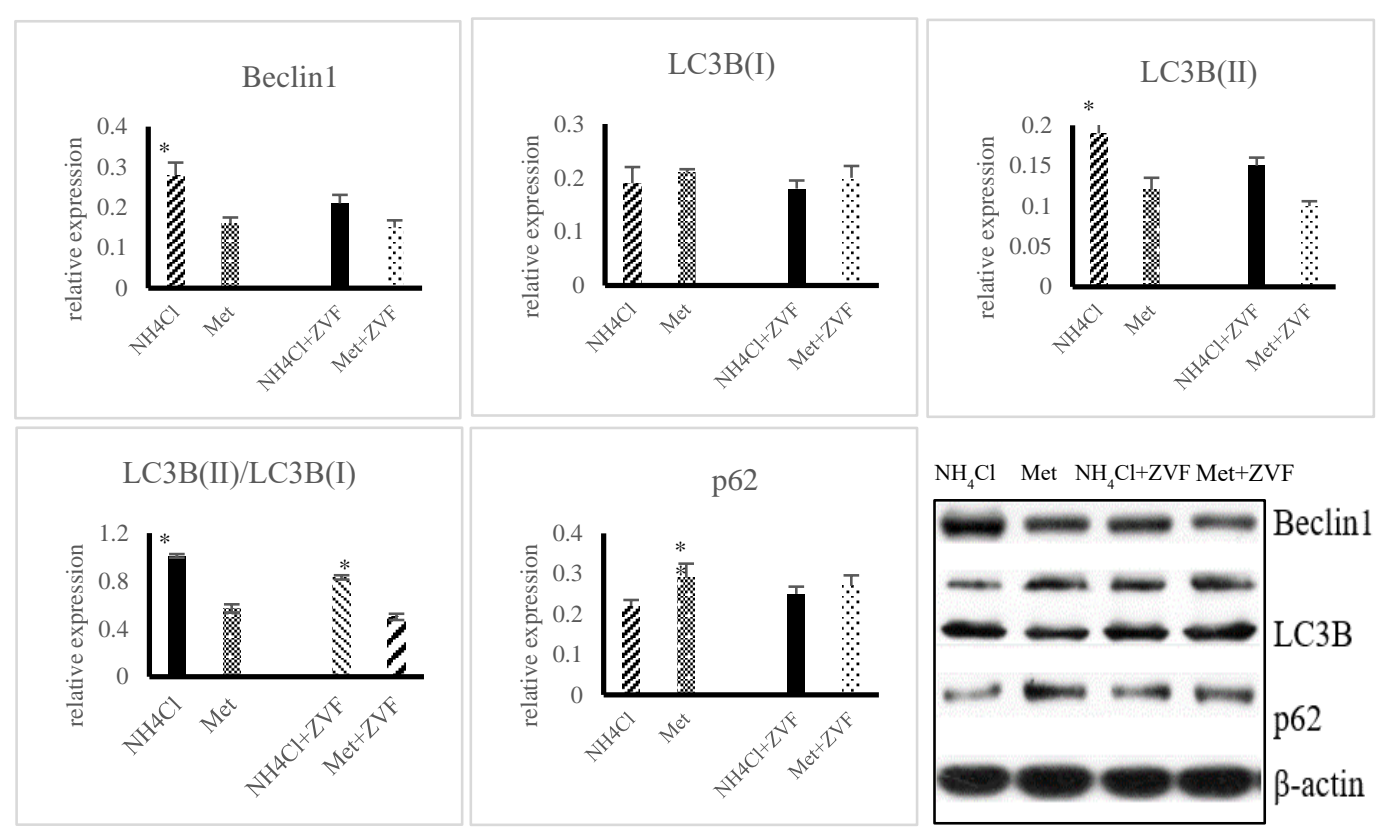

Figure 6. Crosstalk between apoptosis and autophagy induced by $\mathrm{NH}_{4} \mathrm{Cl}$ and Met in PRECs. (A) The role of 3-MA in apoptosis induced by $\mathrm{NH}_{4} \mathrm{Cl}$ and Met was confirmed by Western blot. Each bar shows mean \pm SD. (B) The role of Z-VAD-FMK $(\mathrm{ZVF})$ in autophagy by $\mathrm{NH}_{4} \mathrm{Cl}$ and Met was measured by Western blot.

Western blot analysis was performed in order to determine the effect of on autophagy induced for $36 \mathrm{~h}$. Each bar shows mean \pm SD. 


\section{Discussion}

In ruminants, the self-renewal process of rumen epithelial cells is affected by more factors than that of other types of cells because the rumen is in direct contact with the diet. During self-renewal, the mucosal epithelial cells of the gastrointestinal tissue need to continuously synthesize DNA, RNA, and proteins, and thus proteins from various sources are very important for the growth, regulation, and repair of gastrointestinal mucosal epithelial cells $[23,24]$. In addition, the regeneration and repair of epithelial cells are inseparable from apoptosis and autophagy, which frequently occur in epithelial cells. Therefore, studying the relationships between different nitrogen sources and apoptosis/autophagy is critical.

Apoptosis is an important mechanism of $\mathrm{NH}_{4} \mathrm{Cl}$ toxicity, and ROS contribute substantially to $\mathrm{NH}_{4} \mathrm{Cl}$-induced apoptosis [10]. High levels of $\mathrm{NH}_{4} \mathrm{Cl}$ promote $\mathrm{ROS}$ production, mitochondrial dysfunction, and cytochrome c release, and eventually lead to apoptosis [11]. In the present work, the levels of both ROS and p53 were increased in $\mathrm{NH}_{4} \mathrm{Cl}$-treated cells. We hypothesized that ROS activated p53-regulated mitochondrial apoptosis pathways during $\mathrm{NH}_{4} \mathrm{Cl}$-induced apoptosis. ROS concentrations are correlated with the disruption of mitochondrial membrane potential $\Delta \psi \mathrm{m}$ [25], which is consistent with the results regarding MMP obtained in the present work-the $\mathrm{NH}_{4} \mathrm{Cl}$ group exhibited higher ROS levels than the Met group. When apoptosis occurs, the p53-regulated Bcl-2 protein family (including Bax and Bcl2) activates the mitochondrial apoptotic pathway [26]. In the current study, changes in the relative protein expression of p53 and Bax were positively correlated with changes in the apoptosis rate. p53 can disrupt the Bax/Bcl-2 balance by interacting with Bcl-2 protein in the mitochondria, increasing the permeability of the outer mitochondrial membrane [27]; this phenomenon is consistent with our findings that $\mathrm{p} 53$ levels were higher, while the MMP and Bax/Bcl-2 ratio was lower, in the $\mathrm{NH}_{4} \mathrm{Cl}$ group in comparison with the Met group. Therefore, we conclude that $\mathrm{NH}_{4} \mathrm{Cl}$ induces apoptosis by causing mitochondrial dysfunction.

Autophagy is a lysosomal-dependent degradation pathway and a dynamic process, the last step of which is the fusion of autophagosomes and lysosomes to degrade cytoplasmic substances and organelles [28]. Previous studies have reported that Met deficiency leads to autophagy of glioma cells both in vitro and in vivo [29], consistent with our findings that the levels of autophagy-related proteins and the numbers of autophagosomes were higher in $\mathrm{NH}_{4} \mathrm{Cl}$-treated cells than in Met-treated cells. In this study, we observed significantly increased LC3-II/LC3-I ratios and decreased p62 levels in $\mathrm{NH}_{4} \mathrm{Cl}$-treated cells, which might have resulted from the fact that there is no colocalization between mitochondria and lysosomes when cells are treated with $\mathrm{NH}_{4} \mathrm{Cl}$ under starvation conditions, which leads to decreased autophagy [14]. Therefore, we speculate that autophagy in the $\mathrm{NH}_{4} \mathrm{Cl}$ group was induced by ER stress.

A previous study has revealed that $\mathrm{NH}_{4} \mathrm{Cl}$ induces apoptosis and autophagy through ER stress and mitochondrial dysfunction in MRP2 cells [11]. Thus, we aimed to explore the relationship between ER stress and apoptosis/autophagy induced by $\mathrm{NH}_{4} \mathrm{Cl}$ in this study. Pretreatment with $4 \mathrm{PBA}$ reduced $\mathrm{NH}_{4} \mathrm{Cl}$-mediated induction of apoptosis and autophagy, implying that ER stress helps regulate apoptosis and autophagy in PRECs. In the present work, the levels of CHOP increased with upregulation of Bax and p53 expression in $\mathrm{NH}_{4} \mathrm{Cl}$-treated cells, perhaps because ER stress activated CHOP; triggered Bcl-2, Bak, and Bax expression; and ultimately activated ROS-induced apoptosis [30]. Additionally, a previous study has found that PC12 cells might be injured by ER stress-mediated apoptosis [31]. Furthermore, activation of ER stress pathways has also been reported to be associated with autophagy [32,33]. In the present study, we observed significant increase in LC3-II and a decrease in p62 with increased $\mathrm{CHOP}$ expression in $\mathrm{NH}_{4} \mathrm{Cl}$-treated cells, indicating that the increase in autophagy was associated with the activation of ER stress. In conclusion, ER stress contributes to the apoptosis and autophagy triggered by NPN in PRECs, perhaps because that NPN can promote the occurrence of oxidative stress [34].

Apoptosis and autophagy can occur simultaneously in Bel-7402 cells, and autophagy can regulate apoptosis via phosphorylation of p38 MAPK. However, autophagy promotes cell proliferation and 
survival in response to stress and inhibits apoptosis $[35,36]$. In this study, we found that downregulation of autophagy via treatment with 3-MA significantly intensified apoptosis triggered by oxidative stress in $\mathrm{NH}_{4} \mathrm{Cl}$-treated cells; conversely, inhibition of apoptosis with Z-VAD-FMK alleviated autophagy in $\mathrm{NH}_{4} \mathrm{Cl}$-treated cells. However, we did not find a similar phenomenon in cells treated with Met. Thus, we suggest that autophagy might have a palliative effect on apoptosis in cells treated with NPN compared with protein nitrogen, possibly because that protein nitrogen can better provide the carbon skeleton and energy needed for cellular protein synthesis and can promote cell growth.

\section{Conclusions}

Our results suggest that ER stress contributes substantially to the apoptosis and autophagy triggered by protein nitrogen and NPN. Autophagy has a more obvious ameliorative effect on apoptosis in ruminal epithelial cells treated with NPN than in ruminal epithelial cells treated with protein nitrogen, perhaps because protein nitrogen better suited than NPN for protein synthesis and promotes the resistance of cells to AA deficiency stress.

Author Contributions: Conceptualization, C.Z.; analysis, J.K.; data curation, Z.K.; writing-original draft preparation, Z.K.; writing-review and editing, C.Z. and Z.T.; funding acquisition, C.Z. All authors have read and agreed to the published version of the manuscript.

Funding: This work was supported by the Ministry of Science and Technology of China (2018YFD0501903); the Hunan Provincial Science and Technology Department (2017NK1020); the National Natural Science Foundation of China (No. 31772632); and the Youth Innovation Team Project of ISA, Chinese Academy of Sciences (2017QNCXTD_ZCS).

Conflicts of Interest: The authors declare no conflict of interest.

\section{References}

1. Qi, D.J.; Shi, W.; Black, A.R.; Kuss, M.A.; Pang, X.N.; He, Y.N.; Liu, B.; Duan, B. Repair and regeneration of small intestine: A review of current engineering approaches. Biomaterials 2020, 240, 119832. [CrossRef]

2. Kennedy, P.M.; Milligan, L.P. Input of endogenous protein into the fore stomachs of sheep. Can. J. Anim. Sci. 1980, 60, 1029-1038. [CrossRef]

3. Wang, K.L.; Chu, D.X.; Wu, J.; Zhao, M.L.; Zhang, M.M.; Li, B.J.; Du, W.J.; Du, J.M.; Guo, R.X. Cinobufagin induced cell apoptosis and protective autophagy through the ROS/MAPK signaling pathway. Life Sci. 2019, 116642. [CrossRef]

4. $\quad$ Liu, Z.J.; Hu, Y.L.; Feng, Y.; Guo, Y.B.; Liu, Y.F.; Yang, J.L.; Mao, Q.S.; Xue, W.J. Rafoxanide promotes apoptosis and autophagy of gastric cancer cells by suppressing PI3K/Akt/mTOR pathway. Exp. Cell Res. 2019, 385, 111691. [CrossRef]

5. Tian, Y.; Jia, S.X.; Shi, J.; Gong, G.Y.; Yu, J.W.; Niu, Y.; Yang, C.M.; Ma, X.C.; Fang, M.Y. Polyphyllin I induces apoptosis and autophagy via modulating JNK and mTOR pathways in human acute myeloid leukemia cells. Chem. Biol. Interact. 2019, 311, 108793. [CrossRef]

6. Huynh, T.Y.L.; Zareba, I.; Baszanowska, W.; Lewoniewska, S.; Palka, J. Understanding the role of key amino acids in regulation of proline dehydrogenase/proline oxidase (prodh/pox)-dependent apoptosis/autophagy as an approach to targeted cancer therapy. Mol. Cell Biochem. 2020, 466, 35-44. [CrossRef]

7. Han, Z.Y.; Zhou, G.B.; Jin, Z.H.; Wang, G.L.; Li, H.X. Effects of rumen protected methionine on performance, apoptosis of lymphocytes and related genes in dairy cows under heat stress. Chin. J. Anim. Nutr. 2009, 21, $665-672$.

8. Tan, H.; Yang, K.; Li, Y.; Shaw, T.I.; Wang, Y.; Blanco, D.B.; Wang, X.; Cho, J.H.; Wang, H.; Rankin, S.; et al. Integrative Proteomics and Phosphoproteomics Profiling Reveals Dynamic Signaling Networks and Bioenergetics Pathways Underlying T Cell Activation. Immunity 2017, 246, 488-503. [CrossRef]

9. Yu, J.Z.; Ying, Y.; Liu, Y.; Sun, C.B.; Dai, C.; Zhao, S.; Tian, S.Z.; Peng, J.; Han, N.P.; Yuan, J.L.; et al. Antifibrotic action of Yifei Sanjie formula enhanced autophagy via PI3K-AKT-mTOR signaling pathway in mouse model of pulmonary fibrosis. Biomed. Pharmacother. 2019, 118, 109293. [CrossRef] 
10. Liu, J.; Tan, H.; Sun, Y.; Zhou, S.; Cao, J.; Wang, F. The preventive effects of heparin-superoxide dismutase on carbon tetrachlofide-induced acute liver failure and hepatic fibrosis in mice. Mol. Cell Biochem. 2009, 327, 219-228. [CrossRef]

11. Hayashi, H.; Mizuno, T.; Horikawa, R.; Nagasaka,H.; Yabuki, T.; Takikawa,H.; Sugiyama, Y. 4-Phenylbutyrate modulates ubiquitination of hepatocanalicular MRP2 and reduces serum total bilirubin concentration. J. Hepatol. 2012, 56, 1136-1144. [CrossRef]

12. Zhang, M.Z.; Li, M.; Wang, R.X.; Qian, Y.X. Effects of acute ammonia toxicity on oxidative stress, immune response and apoptosis of juvenile yellow catfish Pelteobagrus fulvidraco and the mitigation of exogenous taurine. Fish Shellfish. Immun. 2018, 79, 313-320. [CrossRef]

13. Bhatia, V.; Singh, R.; Acharya, S.K. Predictive value of arterial ammonia for complications and outcome in acute liver failure. Gut 2006, 55, 98-104. [CrossRef]

14. Kawai, A.; Uchiyama, H.; Takano, S.; Nakamura, N.; Ohkuma, S. Autophagosome lysosome fusion depends on the $\mathrm{pH}$ in acidic compartments in CHO cells. Autophagy 2007, 3, 154-157. [CrossRef]

15. Stamenkovic, M.; Janjetovic, K.; Paunovic, V.; Ciric, D.; Kravic-Stevovic, T.; Trajkovic, V. Comparative analysis of cell death mechanisms induced by lysosomal autophagy inhibitors. Eur. J. Pharmacol. 2019, 859, 172540. [CrossRef]

16. Zhang, M.; Jin, X.; Yang, Y.F. $\beta$-Glucan from Saccharomyces cerevisiae induces SBD-1 production in ovine ruminal epithelial cells via the Dectin-1-Syk-NF-kB signaling pathway. Cell Signal 2019, 53, 304-315. [CrossRef]

17. Ge, H.; Li, Z.G.; Jiang, L.P.; Li, Q.J.; Geng, C.Y.; Yao, X.F.; Shi, X.X.; Liu, Y.; Cao, J. Cr (VI) induces crosstalk between apoptosis and autophagy through endoplasmic reticulum stress in A549 cells. Chem. Biol. Interact. 2019, 298, 35-42. [CrossRef]

18. Dixit, R.; Agrawal, L.; Singh, S.P.; Prateeksha; Singh, P.C.; Prasad, V.; Chauhan, P.S. Paenibacillus lentimorbus induces autophagy for protecting tomato from Sclerotium rolfsii infection. Microbiol. Res. 2018, 215, 164-174. [CrossRef]

19. Ran, T.; Li, H.Z.; Liu, Y.; Zhou, C.S.; Tang, S.X.; Han, X.F.; Wang, M.; He, Z.X.; Kang, J.H.; Yan, Q.X.; et al. Cloning, phylogenetic analysis, and distribution of free fatty acid receptor GPR120 expression along the gastrointestinal tract of housing versus grazing kid goats. J. Agric. Food Chem. 2016, 64, 2333-2341. [CrossRef]

20. Livak, K.J.; Schmittgen, T.D. Analysis of relative gene expression data using real-time quantitative PCR and the 2(-Delta Delta C(T)) Method. Methods 2001, 25, 402-408. [CrossRef]

21. Yan, Q.X.; Tang, S.X.; Tan, Z.L.; Han, X.F.; Zhou, C.S.; Kang, J.H.; Wang, M. Proteomic Analysis of Isolated Plasma Membrane Fractions from the Mammary Gland in Lactating Cows. J. Agric. Food Chem. 2015, 63, 7388-7398. [CrossRef]

22. Karaki, S.; Tazoe, H.; Hayashi, H.; Kashiwabara, H.; Tooyama, K.; Suzuki, Y.; Kuwahara, A. Expression of the short-chain fatty acid receptor, GPR43, in the human colon. J. Mol. Histol. 2008, 39, 135-142. [CrossRef]

23. Tesseraud, S.; Everaert, N.; Ezzine, S.B.; Collin, A.; Berri, S.M.C. Manipulating tissue metabolism by amino acids. World Poult. Sci. 2011, 67, 243-252. [CrossRef]

24. Li, G.W.; Burkhardt, D.; Gross, C.; Weissman, J.S. Quantifying absolute protein synthesis rates reveals principles underlying allocation of cellular resources. Cell 2014, 157, 624-635. [CrossRef]

25. Görlach, A.; Bertram, K.; Hudecova, S.; Krizanova, O. Calcium and ROS: A mutual interplay. Redox Biol. 2015, 6, 260-271. [CrossRef]

26. Westphal, D.; Dewson, G.; Menard, M.; Frederick, P.; Iyer, S.; Bartolo, R.; Gibson, L.; Czabota, R.P.E.; Smith, B.J.; Adams, J.M.; et al. Apoptotic pore formation is associated with in-plane insertion of Bak or Bax central helices into the mitochondrial outer membrane. Proc. Natl. Acad. Sci. USA 2014, 111, 4076-4085. [CrossRef]

27. Klee, M.; Pallauf, K.; Alcalá, S.; Fleischer, A.; Pimentel-Muiños, F.X. Mitochondrial apoptosis induced by bh3-only molecules in the exclusive presence of endoplasmic reticular bak. EMBO J. 2014, 28, 1757-1768. [CrossRef]

28. Levine, B.; Klionsky, D.J. Development by self-digestion: Molecular mechanisms and biological functions of autophagy. Dev. Cell 2004, 6, 463-477. [CrossRef]

29. Liu, H.; Zhang, W.; Wang, K.; Wang, X.; Yin, F.; Li, C.; Wang, C.; Zhao, B.; Zhong, C.; Zhang, J.; et al. Methionine and cystine double deprivation stress suppresses glioma proliferation via inducing ROS/autophagy. Toxicol. Lett. 2015, 232, 349-355. [CrossRef] 
30. Liu, Z.W.; Zhu, H.T.; Chen, K.L.; Dong, X.; Wei, J.; Qiu, C.; Xue, J.H. Protein kinase RNA-like endoplasmic reticulum kinase (PERK) signaling pathway plays a major role in reactive oxygen species (ROS)-mediated endoplasmic reticulum stress-induced apoptosis in diabetic cardiomyopathy. Cardiovasc. Diabetol. 2013, 12, 158-173. [CrossRef]

31. Liu, Y.; Shen, S.; Li, Z.; Jiang, Y.; Si, J.; Chang, Q.; Liu, X.; Pan, R. Cajaninstilbene acid protects corticosterone-induced injury in PC12 cells by inhibiting oxidative and endoplasmic reticulum stress-mediated apoptosis. Neurochem. Int. 2014, 78, 43-52. [CrossRef]

32. Guo, M.L.; Liao, K.; Periyasamy, P.; Yang, L.; Cai, Y.; Callen, S.E.; Buch, S. Cocaine-mediated microglial activation involves the ER stress-autophagy axis. Autophagy 2015, 11, 995-1009. [CrossRef]

33. Periyasamy, P.; Guo, M.L.; Buch, S. Cocaine induces astrocytosis through ER stress-mediated activation of autophagy. Autophagy 2016, 12, 1310-1329. [CrossRef]

34. Murthy, C.R.; Rama Rao, K.V.; Bai, G.; Norenberg, M.D. Ammonia-induced production of free radicals in primary cultures of rat astrocytes. J. Neurosci. Res. 2001, 66, 282-288. [CrossRef]

35. Boya, P.; Gonzalez-Polo, R.A.; Casares, N.; Perfettini, J.L.; Dessen, P.; Larochette, N.; Metivier, D.; Meley, D.; Souquere, S.; Yoshimori, T.; et al. Inhibition of macroautophagy triggers apoptosis. Mol. Cell Biol. 2005, 25, 1025-1040. [CrossRef]

36. Wang, Y.; Xia, C.; Lv, Y.; Li, C.; Mei, Q.; Li, H.; Wang, H.; Li, S. Crosstalk influence between P38MAPK and autophagy on mitochondria-mediated apoptosis induced by anti-fas antibody/actinomycin D in human hepatoma bel-7402 cells. Molecules 2017, 22, 1705. [CrossRef]

Publisher's Note: MDPI stays neutral with regard to jurisdictional claims in published maps and institutional affiliations.

(C) 2020 by the authors. Licensee MDPI, Basel, Switzerland. This article is an open access article distributed under the terms and conditions of the Creative Commons Attribution (CC BY) license (http://creativecommons.org/licenses/by/4.0/). 